\title{
Dynamics of Customary Land Rights and Its Impact on the Agronomic Choices for Small Farmers in the South Kivu province, Eastern DR Congo
}

\author{
Dieudonné Bahati Shamamba \\ Phd Student, Department of Economy and Rural Development, \\ Gembloux Agro-Bio Tech, University of Liège, Belgium \\ Faculty of Agriculture, Catholic University of Bukavu, DR Congo \\ Espoir Bisimwa Basengere \\ Professor, Faculty of Agriculture, Catholic University of Bukavu, DR Congo \\ Philippe Lebailly \\ Professor, Department of Economy and Rural Development, \\ Gembloux Agro-Bio Tech, University of Liège, Belgium
}

DOI: https://doi.org/10.36941/ajis-2021-0165

\section{Abstract}

In Africa, there is still observed a land related legal plurality despite innovations undertaken since colonial times. In DR Congo, while by law land remains the property of the State, it remains difficult to manage rural lands, ignoring customary practices. In fact, alongside the "modern" land administration, the majority of rural lands are covered by customary contracts. Meanwhile, these contracts have evolved due to different socio-political issues in the DRC and particularly in its eastern part. This study aimed at understanding these changes and thus the impact resulted in agricultural activities, especially the small farmers' technology choice. The study is based on households' surveys in the Mbinga Sud zone as well as from other stakeholders on land in the Kalehe territory, South Kivu province, eastern DRC. Through this study, it is noted that customary land contracts have sufficiently evolved due to the population growth, innovations taken in land administration in the country, the wars that occurred in the eastern DR Congo, the attractiveness of rural land by elites and rich businessmen leading to land concentration etc. Given this situation, some practices such as purchase and lease of land were thus developed to cope with weak customary land acquisition mechanisms, the land scarcity and / or land depletion and the fear of land grabbing by the strongest. These changes also have an impact on some agricultural practices, including the fertilization of farms, the choice of crops and varieties to grow as well as many other cultivation techniques.

Keywords: land law, customary, crop choices, small farmer, Kalehe

\section{Introduction}

In Democratic Republic of Congo (DRC) like it is a general case in countries that have experienced colonization and particularly in Africa, there exists a plurality in terms of land management (Chauveau, 1998; Chauveau \& Mathieu, 1998; Keita, 1998; Soro, 2016; Valkonen, 2021). Alongside the 
"modern" legislation resulting from the Belgian colonial administration, there is persistence of local customary rules in the management of land throughout the DRC (Ansoms et al, 2013; Masiala Bode, 2021). The country being large and variously populated, these rules differ from one party to another depending on the particularity of the customs pertaining to each people (Oyono, 2011) ${ }^{1}$.

In the South Kivu province for example, in the eastern DRC, while law defines the rules and procedures to obtain land, most of the land owned by peasants has been acquired or conceded through customary norms (IFDP, CORDAID and ICCO, 2010). Yet customary authorities are no longer legally recognized as land authorities, these continue donating land and maintain control on land transactions taking place in their entities (Lonu et al, 2017). Regarding the increase in land needs due to demographic growth, land rental practices have developed, including on customarily obtained land. Due to these practices, it therefore becomes possible to some people to use land that they do not own, provided that they comply with the requirements of the landlord (Mugangu, 2008).

At the same time, many phenomena occurred over the last two decades in the east of the DRC following the resurgence of conflicts that have characterized this region: especially massive acquisition of land and innumerable land conflicts sometimes resulting to violence (Ansoms et al, 2012). Many authors even consider that ambitions for land resources control and protection as well as related conflicts have considerably contributed to experienced socio-political instability in this part of the DRC, most of the time resulting to violent disputes either between individuals or communities (Ansoms \& Hilhorst, 2012; Claessens et al, 2012). Some land massive acquisitions are also justified by the lack of arrangement between land centred resources management tools, notably agriculture, mining and forests in DR Congo (Eurac, 2017) ${ }^{2}$.

From the preceding lines it is important to note the fragility of peasants' customary rights on land; especially that customary authorities supposed to protect them sometimes appear in their violation (Ansoms et al, 2013). According to van Leeuwen \& van der Haar (2014), in DRC, the customary authorities are increasingly involved in transactions concerning the community lands, yet the land code dedicates these lands to local communities ${ }^{3}$ under the responsibility of customary authorities ${ }^{4}$. In the context of South Kivu and the Kalehe territory especially, considering the impact of land access on the households' welfare (Vlassenroot, 2005), these mainly living on agriculture, it is important to determine the way various peasants' customary land rights evolved over time and due to the evolutions of the socio-political context in the region. This will help determine the way these evolutions could have influenced the agricultural practices of households in this part of South Kivu, in order to formulate guidelines for small farm agriculture regarding eventual limits to be detected. Such is the objective of this paper.

In addition to data got from literature on the Congolese land management in general and South Kivu related peculiarities, this paper also involves empirical data from stakeholders' surveys over land, conducted in 2017 in the territory of Kalehe, in the Mbinga-Sud zone including 120 households, customary authorities, land administration staff in Kalehe, etc. Households were chosen randomly from the household lists in three localities of the Mbinga Sud Zone, namely Cibanda, Bushushu, Munanira and Cibanja. These localities were chosen on the basis of their accessibility and security

\footnotetext{
${ }^{1}$ In fact, customary land acquisition systems are linked to the social and political organization of each people. In forest communities with low central authority in the central part of the DRC, land management is ensured within families and villages by lineage chiefs; whereas in societies heavily centralized in the east of the country, land is concentrated by the customary authorities who manage it (Oyono, 2011).

${ }^{2}$ In DRC, different laws sometimes apply to peasant (agricultural) land where other resources (minerals, forests) are likely to be exploited. There is unfortunately a superiority of mining and forestry codes on the Agricultural one (Ntapaka 2008; Eurac, 2017). Regarding this situation, lots of peasant lands have been lost.

${ }^{3}$ See in this regard articles 388 and 389 of law $n^{\circ} 73-021$ of July 20,1973 known as the land law in DRC

${ }^{4}$ Article 10 of Law 15/o15 of August 25, 2015 establishing the status of customary authorities defines, but not limited to, the missions of a customary authority in DRC: "to ensure, in accordance with the law, the protection of local communities lands".
} 
aspects. To achieve its objective, this study first tries to identify customary land rights practiced in Kalehe territory, their security aspect and their evolution; then it analyses the influence of these evolutions on peasants' technical agricultural choices. For data processing, MS Excel has been used to generate graphs and calculate some frequencies.

\section{Identification of Customary Land Rights in the Kalehe Territory}

In regions with an agricultural tradition, as such is generally the case in Africa, land is a community heritage that should not be subject to the right of disposal as per the European conception of property (Mansion \& Broutin, 2014). It is a heritage received from ancestors and owed to descendants. Its management is thus warranted by the customary authority (here referred to as "Mwami ") for the benefit of the whole community (Karsenty and Assembe, 2010; Oyono, 2011). From the custom perspective, the different ways of access to land should therefore define mechanisms of use excluding any appropriation mechanism.

In Buhavu like in Bushi5, according to the report of the round table held in Bukavu in 2010 on land issues and related challenges in the South Kivu province, two main customary modes of access to land are practiced, namely kalinzi and bwasa. Speculations on land have led to the development of a third practice, the bugule (IFDP, CORDAID and ICCO, 2010). The kalinzi designates both the price of the right of use and the land on which this right is applied. From political view, it is considered as the price of the right of use that the suzerain receives from the vassal and his descendants. It is therefore not a purchase price but rather a right of recognition from the vassal to the suzerain who assigns him land "ownership". It consists of a number of cows and / or goats. Its value depends on several factors including the size of the plot, its fertility, the degree of friendship, the degree of offer and demand of land in the region. The kalinzi is acquired according to the pyramid of social relations within the customary entity as follows: from the Mwami to the Murhambo, the Murhambo to the Mushamuka, and from the Mushamuka "6 to people for whom he is responsible and each individual to any third party up to individual plots. Kalinzi is transmissible to descendants and remains renewable each year following the reverse direction of the pyramid given above, namely from individuals to the Mwami through the Bashamuka and the Barhambo who canalize it to the Mwami ${ }^{7}$ (Mugangu Matabaro, 1997). Renewable on yearly basis, the kalinzi can be assimilated in the "modern" law to land tax that citizens holding a land title are obliged to pay to the State each year.

The bwasa, however, designates a 'rental contract giving the borrower the right to use land for a short period (often one harvest and at most one year, i.e. two growing seasons) and the related rental price is generally calculated taking into account the profits made and is therefore paid after the harvest'. It mainly concerns seasonal and annual crops. It can be attributed by any "landowner" from the Mwami, the Murhambo, the Mushamuka to any individual, each one on the part of his owned land that he has not attributed to someone else (Ouchinsky, 1966). Practically speaking, it should be noted that bwasa means sharecropping. But rather than posteriorly paying the fee, households in

\footnotetext{
${ }^{5}$ Buhavu is the geographical extent inhabited by the Havu ethnic group (plural Bahavu). In South Kivu, the Bahavu inhabit mainly the territories of Kalehe and Idjwi. As for the Bushi, is inhabited by the Bashi ("Shi "in singular); they are currently spread mainly in the territories of Kabare, Walungu and Mwenga. The two groups have very similar cultural norms.

${ }^{6}$ The structure of the society in both Bushi and Buhavu is organized in a hierarchical manner as follows: The Mwami who is the Chief, designates a Murambo who controls a large entity subdivided into villages headed by village chiefs. In the villages, we have heads offamilies, the Bashamuka (plural of Mushamuka).

${ }^{7}$ According to the chief of Cibandja village in Kalehe, the renewal of the kalinzi by the citizens is done in terms of the recognition by the latter for the benefits they got from the Mwami through the land they have got from him. The Bashamuka collect the kalinzi from citizens up to the locality chief (here referred to as Murhambo) who brings it to the Mwami at the end of each year. Through this collection, the Mwami expects to receive a cow from Cibandja village every year. Other villages with larger population sizes have to give more (Interview with the locality chief of Cibandja, March 2020).
} 
Kalehe are required to pay it in advance ${ }^{8}$. This currently stands for source of income for the elites with huge lands given the households' high need for land.

The bugule means the purchase of land for " full ownership " whereas the kalinzi does not confer a property right to its holder as seen previously; the verb kulinza meaning "to entrust something to ... ", "to put in the care of ... ". The bugule therefore stands for a form of adaptation to the property regime established by the Belgian colonial administration. So, it is mistakenly considered as a traditional contract according to Mugangu Matabaro (1997). Even when land is obtained under the bugule, "the concerned person is bound to comply with the customary requirements. He has the obligation to pay customary related fee to the Bashamuka, who have to send it to whom it may concern, according to the diagram indicated above 9 .

Of all the forms of contracts given above, only the kalinzi can be considered as customary contract, the bwasa came up in order to cope with the scarcity of land which gradually occurred while the bugule arose with the need for the natives to line up with modern law advocated by the colonizer (Mugangu Matabaro, 1997). In fact, Karsenty \& Assembe (2010) noted that customary land acquisition systems have sufficiently interacted with the 'modern' regime and the social alterations that have taken place over time justify some of the changes they have undergone. Thus, the bugule is currently widespread. It can be considered as a peasant strategy toward the current challenge to obtaining land from the customary authorities through the kalinzi contract. Considering the social value attributed to land in the area, everyone would like to have some owned portion of land. Nevertheless, given the increased land bidding developed in rural areas of South Kivu and due to the attractiveness of rural land on the side of elites (Utshudi Ona, 2008), the bugule is predominant on small plots. These small portions of land are mainly used for construction of dwelling houses and installation of small housing fields. So, peasants are unable to acquire large dimensions of land due to poverty.

\section{Methodology}

This study was conducted in Kalehe, one of the eight territories that make up the province of South Kivu. Kalehe is located in the northern part of South Kivu on the edge of Lake Kivu. It is one of the places characterized by strong competition for land mainly maintained by a rapid increase in population as by the concentration of land by elites linked in particular to land grabbing practices in South Kivu. As a consequence, land disputes are very common in the area; some even involving violence (Ansoms et al, 2012; Classaens et al, 2012). Therefore, Kalehe presents a good example for understanding the current context of access to land in rural areas in South Kivu, characterized by strong competition for land (Vlassenroot, 2005). As the population lives mainly on agriculture (PNUD, 2009), it would be necessary to determine the way this context of access to land has evolved in the area, the factors at the base of this evolution and the strategies developed in order to face it, and above all the impact of this situation on household agricultural activities. As agriculture is essentially family-run in the region (Bahati Shamamba et al., 2021), this work might help to understand how this development by influencing cropping techniques can influence agricultural production and consequently household livelihoods. Therefore, it could serve to orient rural development policies in the east of the DRC.

In order to achieve this, a households' survey was conducted in the Mbinga Sud zone in the localities of Cibanja, Cibanda, Munanira and Bushushu, territory of Kalehe. The choice of the zone and the localities was made on the basis of security parameters and accessibility. Furthermore, Mbinga Sud represents, with local densities more than 400 inhabitants $/ \mathrm{km}^{2}$ in some places (ICCN, 2010), one of the densest areas in Kalehe territory. The phenomena of population movements (details

\footnotetext{
${ }^{8}$ In farms belonging to large landowners, payment is made in cash (\$50 to \$ 75 for a size of 50mx25m) with additional few days of work per month on this farm consisting of, but not limited to, participating in the rehabilitation activities of roads within the plantation, weeding of food or perennial crops, harvesting fodder for livestock, etc.).

${ }^{9}$ Interview with the locality chief of Cibandja, March 2020.
} 
at the point 4.2) and the attractiveness of land by elites amplifies here the land competition encountered in Kalehe. The sample used in this research was based on the principle of large numbers under which a size of 120 statistical units ensures normal distribution of parameters under study and to make statistical inference. Thus, in each of the 4 localities taken into account, a sample of 30 households was considered in order to have a total of 120 households to be surveyed. In different localities, the 30 households were drawn randomly using the method of successive draws without replacement using the Bernouilli urn technique as follows:

- Initially, the chiefs of the different concerned localities were asked to establish a list of 100 households based on the following criteria: a minimum seniority of 5 years in the locality and active involvement in agricultural activities by the household. The size of 100 households, more than three times the sample to be surveyed in the locality, was considered in order to further diversify the sample and thus to obtain the variability of the data sought for the study. Each household was identified through the name of its head;

- The names of the households' heads on the list were cut out with a pair of scissors. The piece of paper with the name was rolled up into a ball and slipped into a black plastic bag used as an urn. The pieces of paper were cut with the same size in order to obtain balls of the same size as well.

- The balls were drawn progressively and without replacement; by mixing them each time in the bag to assure randomness with each draw. The operation was repeated 30 times in each locality. For each ball drawn, the paper was unrolled to discover the identity of the chosen household. Thus, the names of 30 households were obtained for each locality.

The different households could be identified thanks to guides found in the localities, the interviews having been carried out at the homes of the concerned. Data collection from households was carried out using a survey questionnaire that helped to get information relating to the availability of land for households (including the mode of access to land, the number and size of fields used by households), agricultural practices in relation to the modes of access to land, etc. The surveys took place from October to November 2017. MS Excel helped for the data processing, to generate graphs and to calculate some results for some parameters analysed in the work (mean, standard deviation, frequency, etc.).

The practice of leasing land becoming increasingly important as a result of the need for land for agricultural activities, it was important to understand the context of leasing land in the area and especially the requirements that households are subject to in this practice. Households leasing land in the former colonial plantations located in the area, a sample of 8 plantations was thus considered in Mbinga Sud, namely Ihusi, Katashola 1, Katashola 2, Luzira, Nyambasha, Lemera, Buloho and Kabira. The information in each of them was obtained through discussions with their managers, using an interview guide.

The information received from households and from large plantations was supplemented by the additional one obtained from other stakeholders around land in the area, namely the state administrative authorities, customary authorities, land administration, local farmers' associations, NGOs interested in land issues, churches, etc.

\section{Evolution and Security of Customary Land Rights in Kalehe}

Several factors have contributed to the evolution of the customary land context in the South Kivu province in general and in the Kalehe territory in particular. Among these factors, we have, but not limed to, the population growth, the socio- political context in the region, and the legal innovations in land acquisition process as observed over time in DRC (IFDP, CORDAID and ICCO, 2010; Ansoms et al., 2012; Van Leeuwen \& van der Haar, 2014).

\subsection{Population Growth}

The South Kivu province is facing a rather high rate of population growth. Between 1984 and 2017, the 
population tripled (PNUD, 2009; INS, 2019) ${ }^{10}$. The territory of Kalehe ranks among the zones that have enormously contributed to this growth. In the Mbinga Sud zone for instance, population doubled in a 10-year period between 2008 and 2017. This zone is among the rural areas with high densities within the South Kivu (ICCN, 2010), as seen previously.

This population growth is coupled to obvious competition for land that spaces are increasingly saturated. 'The entire land has been occupied that I no longer have the possibility to give land to no one', said the chief of the Cibandja locality in Kalehe territory ${ }^{11}$. Consequently, the kalinzi is increasingly being replaced by the bugule (purchase) and the bwasa (rental) as explained earlier, is especially maintained in the area by young farmers. Indeed, when the latter have not inherited land, they are obliged depending on their means, to buy or rent it. A rate of 89 out of 384 fields (23\%) used by the surveyed households were rented out (see graph 1 ).

Consequently, people coming from families with insufficient land resources and unable to purchase land, will be challenged in the future, both themselves and their offspring. From the surveyed 120 households in Mbinga Sud in 2017, it was noticed that 11 households had no owned land. The latter survive thanks to leased land. This precarious land situation for young people convincedly explains the rural exodus to the cities of Goma and Bukavu as well as the displacement to artisanal mining sites located in the area or elsewhere.

\subsection{Socio-Political Situation in the Region}

The experienced insecurity situation in the eastern part of the DRC, over the past two decades, negatively impacted on life -in all its aspects- of the people living in this part of the country. Lust for taking control over land has sufficiently fuelled this insecurity, particularly in the territory of Kalehe; armed groups came up to secure the land assets of their communities. This resultantly led to many cases of land grabbing documented in this part of the DRC (Ansoms et al, 2012). The demographic history of this territory including populations movements to neighbouring countries mainly including Rwanda and the provinces of North and South Kivu since colonial times justifies this competition over land and huge related consequences according to many authors ${ }^{12}$. The report of the round table on the land issue in South Kivu mentioned above, shows that one of the factors of land-based insecurity in Kalehe is mainly the conflicts between the Rwandophone communities and the others. "The former had fled the hostilities and took refuge in Rwanda and currently, they are trying to return but most, it seems, sold their land before their departure to Rwanda"13, report IFDP, CORDAID, and ICCO (2010).

\subsection{Legal Innovations in Land Issue in DR Congo}

Despite of the innovations made in land matters in DR Congo, most of the rural land owned by

\footnotetext{
${ }^{10}$ By cross-checking the data on the population highlighted on the profile of the province of South Kivu by PNUD (2009) and the statistics on population developments by province in the DRC from the Institut National de Statistiques, INS (2019), the population of South Kivu increased from 2,107 988 in 1984 to 6,157 000 in 2017.

${ }^{11}$ Interview conducted in March 2020

${ }^{12}$ On this subject matter read, for example, Claessens (2017).

${ }^{13}$ People movements are still being observed in Kalehe. In their letter $n^{\circ}{ }_{42} / B C S C / B^{\prime} K I R I / P D T / 2020$ of December 19, 2020 addressed to the Governor of the South Kivu province, the civil society coordination office of Bunyakiri in Kalehe territory lists three recent waves of Rwandophone people (Hutu and Tutsi) in the highlands of Kalehe occurred in October 2018, January 2019 and June 2020. For the last wave, the civil society shows that more than 25, 000 people entered in Kalehe from the North Kivu province. According to this civil society, these people introduced themselves as refugees while behind this movement there is land control ambitions. The same problem is tackled in the oral question of January 6, 2021 from the Provincial Deputy Mapenzi Malira Paulin, elected from Kalehe, addressed to the Provincial Minister of the Interior affairs, Security, Decentralization and Customary Affairs of the South Kivu province. The deputy asks the minister in particular to enlighten the opinion on the identity of these displaced persons and the reason for the choice of the territory of Kalehe and the villages where they settled.
} 
peasants has been acquired through customary way ${ }^{14}$, pursuant to customary procedures discussed in point 2 and mainly through the kalinzi mode in Buhavu. Over time, peasants' customary land rights have been weakened through the following factors:

- Incoherence in the land law in DRC: the land law in DRC states, articles 388 and 389, that the community lands acquired through customs would be regulated by a Republic President's decree. Unfortunately, this one has never occurred. This situation weakens especially small farmers confronted to strong individuals who would maliciously obtain official titles on their land, sometimes with the complicity of traditional authorities and land administrator that were supposed to protect them (Van Leeuwen \& van der Haar, 2014; Eurac, 2017).

- Poverty: during our surveys, households showed their good will to comply with the law and register their land at state services ${ }^{15}$ but are limited by poverty. It is indeed necessary to allocate at least a sum of 300 US dollars ${ }^{16}$ for this sake. Thus, households are obliged to get satisfied with the recognition of their land by the customary authority, but this does not stand for guaranty with regards to permanent pressure over rural land by financially strong individuals.

- Lack of overlap between the legal instruments regulating land management: several laws regulating the management of soil, subsoil and related dependence in DRC, with reference to the land law, the mining code, the forest code and the agricultural code. There are contradictions and inconsistencies at several levels between these different laws as noted by many authors including Bruneau (2012). For instance, the superiority of a mining license over a land title on the same land. Particularly in South Kivu, peasants have already been victims of this situation, as they were expelled from their land without fair and equitable compensation for their rights ${ }^{17}$.

- $\quad$ Land conflicts: Several land conflicts are listed in South Kivu as corollaries of the problems listed above. These conflicts are the most frequent at the Peace Courts in rural areas of South Kivu (IFDP, CORDAID and ICCO, 2010). At the household level, the latter are mainly linked to disputes due to the problems of sharing inheritance land - inheritance being the main mode of access to land in the area - and to the plots boundaries.

To deal with different factors that negatively influenced the small farmers land rights, some solutions have been developed for the security of customary land rights in Kalehe, including:

- The obtaining of an "Acte de jouissance et d'occupation d'un terrain coutumier"18: This document is obtained through participatory and transparent process particularly involving neighbours in order to prevent possible conflicts. The document is recognized even by the local land administration. According to local land administration, this act stands for a basic document to support titles obtention process from their service, said a land administration

\footnotetext{
${ }^{14}$ Article 183 of the law No 73-021 of July 20, 1973, mentioned above, lists state services authorized to allocate land in DRC. For each service, competence is defined regarding the size of land to be granted either in urban or in rural areas. Customary authorities are not among them.

${ }^{15}$ On subject regarding the evolution of customary land rights in rural Africa, Lavigne Delville (1998) notes a trend towards private property currently enshrined in "modern" law in the sense that: “... for some, customary rights become unclear when demographic pressure and market integration increase. This creates an insecurity that can only be resolved through individual and private appropriation of land. Land matter security model is then implicitly or explicitly private property" [translated from French by ourselves].

${ }^{16}$ Interview with an agent from the Kalehe land administration in May 2019.

${ }^{17}$ For further information, read Namegabe and Murhula (2013) on the relocation of peasants for the establishment of the Twangiza mine by Banro corporation company in the territory of Mwenga in South Kivu

${ }^{18}$ This act was elaborated with the support of Action pour la Paix et la Concorde (APC), a NGO based in Bukavu with the support of its partners under a project aimed to prevent land conflicts in the Kalehe territory (see for more information https://apcasbl.org/, consulted on 10/16/19).
} 
agent ${ }^{19}$. In Kalehe, this act is issued by the chiefdom for a sum of 25 US dollars. Efforts should be made to sensitize the community for the appropriation of this initiative as only 25 households out of more than 500 targeted households had already acquired this document in May 2019, more than two years after its implementation. ${ }^{20}$

- Registration of land plots with land administration: land registration with the land administration is expensive comparatively to the peasants' standards of living as seen previously. Thus, only households with improved livelihoods are able to engage in such as process. For example, only $4 \%$ of surveyed households were able to register their land with the land administration. A Mushamuka met at Kalehe Center showed us that for his case, the Mwami encouraged him to register his land: " the Mwami himself advised me that given the challenging land competition and that has been fuelling up community greediness, I had better register my land with the land administration services to secure them"21.

\section{Impact of Changes in Customary Land Rights on Farmers' Agronomic Choices.}

As discussed previously, three types of land contracts are mainly practiced by small farmers in Kalehe, namely the kalinzi, the bugule and the bwasa. Considering the evolution of these contracts, we can currently note that pieces of land under kalinzi or bugule are households owned fields while the current application form of bwasa will refer to rental. From the surveys carried out, three modes of access to land by households were identified, namely inheritance, purchase and rental. The average age of surveyed households chiefs being 33 years old (minimum: 21 years, maximum: 71 years), it should be considered that the inherited land is essentially from the kalinzi and that purchasing practices on land (bugule) in this area, like in other rural areas of South Kivu, are the result of the increase in the population and the land needs that followed, as particularly highlighted by Mugangu Matabaro (1997). Figure 1 gives the status of land on the surveyed households fields in Kalehe ${ }^{22}$. The latter exploit a minimum of 1 and a maximum of 10 fields.

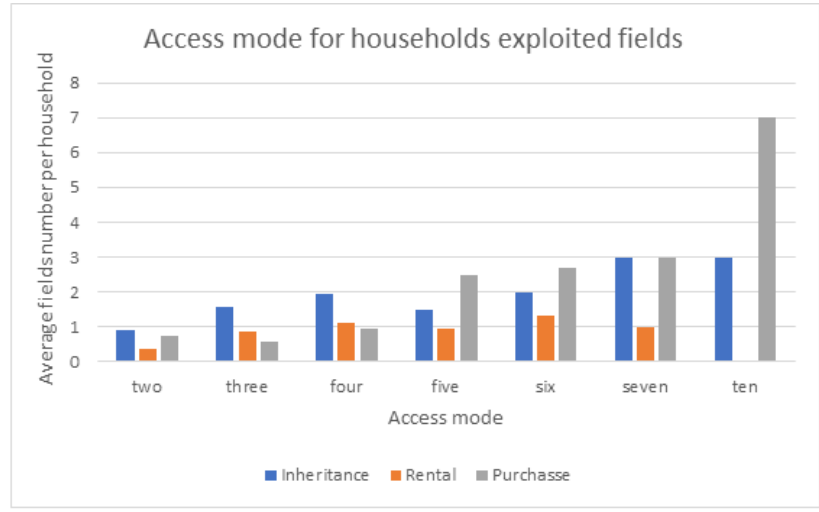

Figure 1: Access mode to the different fields used by the surveyed households in Kalehe. Source: Survey data

\footnotetext{
${ }^{19}$ Interview conducted in May 2019

${ }^{20}$ Interview with the Administrative Secretary of the Chiefdom of Buhavu, May 2019.

${ }^{21}$ Interview conducted in February 2020

${ }^{22}$ In the figure 1, it is shown for a given number of fields exploited by households the mode of access to each one. For some consistency, the results are given from a minimum of 2 fields. It should be noted that 92.5\% of surveyed households exploit a minimum of 2 fields.
} 
The results in Figure 1 highlight the fact that inheritance is the main mode of access to land in rural areas in South Kivu. This is linked to traditional practices in the area, whereby when the parent dies, his land is divided among the members of his male offspring. Even during his lifetime, the parent is obliged to give land to his son when the latter gets married. It should nevertheless be noted that inheritance predominates as a mode of access for households exploiting little land (maximum 4 fields). This is explained by the size of households generally high in the area (average 7 for the surveyed households); that limits the number of fields to be shared by different family members.

From the same figure 1, it is seen that the acquisition of land by purchase has further increased in the area. It covers the average of all the fields exploited by surveyed households. This situation is justified by the evident difficulty in obtaining land by inheritance as seen previously. Nevertheless, in relation to land speculation seen in rural areas in South Kivu and in Kalehe in particular ${ }^{23}$, not all households are able to acquire land by purchase (only $39 \%$ of surveyed households were able to buy within a 10 year period, for example, an average plot of 0.25 ha $)^{24}$. Consequently, only households with sufficient means have the capacity to have and exploit a greater number of fields. From the results of Figure 1, it can be seen that purchase predominates as mode of access for households exploiting a minimum of 5 fields. For poor households, purchase is limited to residential plots as seen previously. In order to survive, they are forced to rent out the fields they exploit.

Land rental practice in Kalehe is extended on almost all fields with variable frequencies (as shown in Figure 1, with more detail in Figure 2 below) is due to two major factors. Firstly, people rent land for lack of their own land mainly due to poverty (11 out of 120 households, for example, having no owned land are obliged to rent all the fields they cultivate). Secondly, people rent land in search for more productive land. Indeed, Kalehe having a rugged terrain, most households have fields on sloping land, continuously exposed to erosion (Bahati Shamamba et al., 2021). These lands therefore quickly lose their fertility since erosion control practices are not implemented. Households are therefore obliged to rent out land in former colonial plantations in which, due to a less uneven relief $^{25}$, the land is less exposed to erosion and therefore potentially more fertile. The constraint for the lease of land remains the rental costs as well as other requirements as already seen.

\footnotetext{
${ }^{23}$ Kalehe ranks among the rural areas where land is expensive in South Kivu. A comparison between land purchase price data between Kalehe and Walungu territories shows that the average purchase price value of 1 ha in Kalehe was $\$ U S$ 3,185 in 2017 while it was \$US 2,246 in Walungu. The data from Walungu - another territory in the South Kivu province - come from interviews conducted in Walungu during our research.

${ }^{24}$ Result of our investigations in Kalehe

${ }^{25}$ It has to be noted that most of the old plantations are located on mountains foot along the Lake Kivu or on plateaus. One example is the Luzira and Kabira plantations, which respectively had 185 and 150 tenant households in 2017.
} 


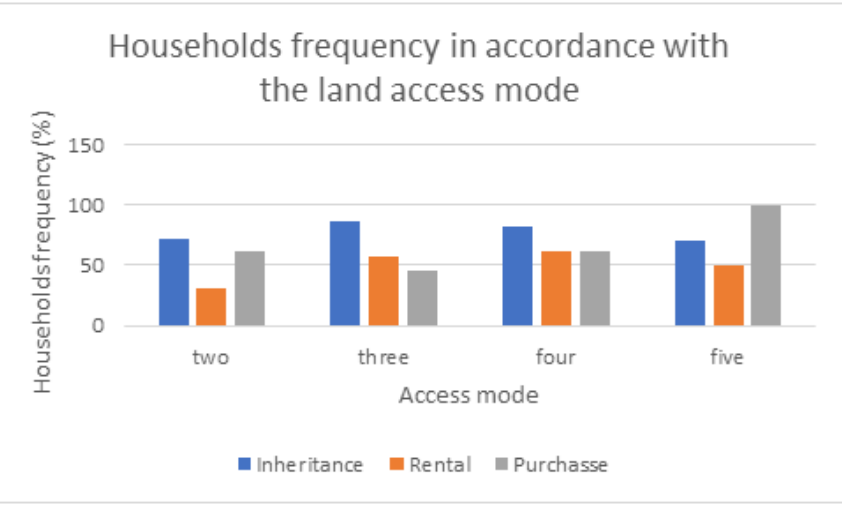

Figure $\mathbf{2}^{\mathbf{2 6}}$ : households frequency according to modes of access to various cultivated lands. Source: Survey data

Table 1 presents some data and agricultural practices related to the status of land in various fields exploited by the surveyed households ${ }^{27}$.

Table 1: Some data and agronomic choices according to various modes of access to land

\begin{tabular}{|c|c|c|}
\hline \multirow{2}{*}{ Parameters } & \multicolumn{2}{|c|}{ Access modes } \\
\hline & Kalinzi, Bugule (property) & Bwasa (rental) \\
\hline Terms of acquisition & $\begin{array}{l}\text { Inheritance for the kalinzi; } \\
\text { Purchase for the bugule }\end{array}$ & Payment of rental fees \\
\hline Households concerned & $\begin{array}{l}\text { Inheritance : } 92(77 \%) \\
\text { Purchase : } 74(62 \%)\end{array}$ & $57(47 \cdot 5 \%)$ \\
\hline Average field sizes & $\begin{array}{l}\text { Inheritance : o.8ha (standard deviation: } 1.3 \text { ha ; } \\
\text { Minimum :o ha ; Maximum : 9ha) } \\
\text { Purchase : o.5ha (standard deviation: } 1.3 \text { ha ; } \\
\text { Minimum : oha; Maximum : 8ha) }\end{array}$ & $\begin{array}{l}\text { o.13ha (standard deviation: o.2ha ; Minimum : oha ; } \\
\text { Maximum : 1.5ha) }\end{array}$ \\
\hline $\begin{array}{l}\text { Frequency of } \\
\text { households according } \\
\text { to the average size of } \\
\text { cultivated fields }\end{array}$ & $\begin{array}{l}\text { Inheritance: } \\
\text { <o.5ha: } 82 \% \text {; } \\
\text { o.5-1ha: } 14 \% \text {; } \\
\text { > 1ha: } 4 \% \\
\text { Purchase: } \\
\text { <0.5ha : } 94 \% \text {; } \\
\text { o. } 5 \text {-1ha : } 5 \% \\
\text { > 1ha : } 1 \%\end{array}$ & $\begin{array}{l}<0.5 \text { ha : } 85 \% ; \\
\text { o.5-1ha : } 7 \% \text {; } \\
>\text { 1ha : } 8 \%\end{array}$ \\
\hline $\begin{array}{l}\text { Duration of the } \\
\text { contract }\end{array}$ & undetermined & 1 year renewable \\
\hline \multicolumn{3}{|l|}{ Cultural practices } \\
\hline - Fertilization & $\begin{array}{l}\text { Use of organic fertilizers; mainly in fields } \\
\text { installed on residential plots }\end{array}$ & Low or no use of organic fertilizers \\
\hline - Erosion control & $\begin{array}{l}\text { Weak application of anti-erosive hedges based } \\
\text { on Tithonia diversifolia, Tripsacum or } \\
\text { Pennisetum purpureum. } \\
\text { Practices such as discontinuous ditches } \\
\text { following the contour lines, ploughing in dams } \\
\text { are not applied. } \\
\text { Mulching is only applied in banana fields }\end{array}$ & $\begin{array}{l}\text { Non-application by renter households. However, if } \\
\text { some devices are present on the leased land, renter } \\
\text { households benefit from them. This is essentially the } \\
\text { case of agroforestry ensured by trees found here and } \\
\text { there in the plantations where the land is rented. }\end{array}$ \\
\hline
\end{tabular}

${ }^{26}$ The results of figure 2 are given for five fields in order to bring out the different frequencies much more clearly. In fact, less than 3 households out of the 120 surveyed exploit more than 5 fields.

${ }^{27} \mathrm{~A}$ total of 384 fields were found for the 120 surveyed households; with a minimum of 1 and a maximum of 10 fields per household as already indicated. 


\begin{tabular}{|c|c|c|}
\hline \multirow{2}{*}{ Parameters } & \multicolumn{2}{|c|}{ Access modes } \\
\hline & Kalinzi, Bugule (property) & Bwasa (rental) \\
\hline - Main crops & $\begin{array}{l}\text { Food crops: cassava, banana, beans, maize, } \\
\text { soybeans, peanuts, etc. } \\
\text { Perennial crops: coffee, cinchona, mainly } \\
\text { eucalyptus-based woodland }\end{array}$ & $\begin{array}{l}\text { Annual food crops only, mainly cassava combined } \\
\text { with other crops such as beans, groundnuts, } \\
\text { soybeans }\end{array}$ \\
\hline - Varieties used & Improved and traditional & Improved and traditional \\
\hline - Prohibited crops & Any & $\begin{array}{l}\text { Perennial crops and sometimes certain crops } \\
\text { considered too wearing soil; example sunflower in } \\
\text { some plantations }\end{array}$ \\
\hline $\begin{array}{l}\text { - Row cropping and } \\
\text { respect for the spacing } \\
\text { between plants }\end{array}$ & $\begin{array}{l}\text { The sowing is a broadcast one without respect } \\
\text { for spacing between plants. Only the coffee } \\
\text { tree and woodland are established while } \\
\text { respecting the spacing for some households }\end{array}$ & $\begin{array}{l}\text { Broadcast sowing without respecting the spacing } \\
\text { between plants. }\end{array}$ \\
\hline - Crop rotation & $\begin{array}{l}\text { Households continuously cultivate the same } \\
\text { crops. No specific crop rotation observed. }\end{array}$ & no crop rotation observed \\
\hline - Association of crops & $\begin{array}{l}\text { Various crops are associated but without } \\
\text { taking any requirement into account. Food } \\
\text { crops are associated with each other and } \\
\text { sometimes with perennial crops including } \\
\text { coffee. Only eucalyptus-based woodlots are } \\
\text { pure }\end{array}$ & $\begin{array}{l}\text { Authorized food crops are combined without } \\
\text { respecting any criteria. In the same field, more than } 5 \\
\text { crops can easily be identified. }\end{array}$ \\
\hline $\begin{array}{l}\text { - Requirements for the } \\
\text { use of land }\end{array}$ & $\begin{array}{l}\text { Customary royalties for people attached to } \\
\text { custom }\end{array}$ & $\begin{array}{l}\text { Rental fees and other requirements according to the } \\
\text { lessors }\end{array}$ \\
\hline
\end{tabular}

\section{Source: surveys data}

From the results of Table 1, it is noted, as previously indicated, that inheritance constitutes the most widespread mode of access to land in Kalehe, $77 \%$ of the surveyed households exploiting at least one inherited field; the $23 \%$ having no fields by inheritance highlight the difficulty of access to land as already mentioned. $62 \%$ of households exploit fields acquired by purchase while $47.5 \%$ exploit leased ones. The fields size obtained from inheritance (o.8ha) are much larger than those obtained from both purchase (0.5 ha) and rental (o.13ha) due to the price of land and the high rental in the area. At the same time, it can be seen that the majority of households exploit very small plots: over $80 \%$ exploit on average less than 0.5 ha for any mode of access to land. For inheritance, due to population growth, inherited lands are continually divided according to the offspring size. This land fragmentation constitutes a strong threat to peasant agriculture in sub-Saharan Africa. Here, 90\% of households farm less than 5 ha (Jayne et al, 2017). For rental, the price does not encourage renting large plots. In particular, due to poverty, households acquire small plots by purchase.

Regarding cultural practices, the following was observed:

- Fertilization is poorly practiced because of the low availability of fertilizers linked to low breeding practice in the area and the poverty to acquire mineral fertilizers (Lunze, 200o; Civava et al, 2013). Thus, small quantities of organic fertilizers from the low number of livestock and household waste are oriented mainly in the fields located in the housing plot. Despite the proximity ${ }^{28}$, ownership influences fertilization reflexes for these fields, and hence provide potential higher productivity. For fields that are not households owned, in addition to the distance to be covered and therefore the weight to be transported, households are not motivated to fertilize them because of precarious rental contracts lasting one year without guaranteed renewal.

- The same reasoning on land fertilization is also appropriate for anti-erosion practices. This practice is currently weakly practiced in the area (Heri-Kazi \& Bielders, 2020), even on owned fields. This is the reason for the continual loss of their fertility as mentioned above

${ }^{28}$ Apart from the housing field, the others are averagely located at a distance of 49.5 minutes walking according to data from our surveys. 
and the reason for the search for rental fields.

- Regarding current crops, some differences can be noticed: food crops are mainly practiced everywhere and on all types of fields depending on the duration of the crop cycle. For example, crops like bananas are not grown on leased land. Similarly, cassava grown on rented land is harvested after just twelve months. The choice of cassava on these lands is justified at the same time by its value on the market that allows to collect back funds paid for the rental; in addition to beans, peanuts or soybeans grown in the interlines. On leased land, therefore, only crops that complete their cycle in one year are tolerated, therefore perennial crops such as coffee and afforestation are only cultivated on own land, that constitutes an additional source of income for households with some available land.

- The most cultivated varieties in Kalehe are traditional ones. Improved varieties have particularly been introduced by NGOs for a few important crops. For cassava, for example, varieties have been popularized as part of the fight against African cassava mosaic. Most of the improved cassava varieties introduced in Kalehe are sweet varieties. The latter are unfortunately continuously stolen from the field, especially by shepherds because of the sweetness of their tubers which does not require any processing before consumption. These varieties are therefore only cultivated on fields that are easy to monitor, the housing ones, which are the property of households. On leased fields, due to the distance from the household's residence, traditional varieties that are generally bitter are cultivated. The bitterness of the latter ensures their protection against attempted theft. Unfortunately, these varieties do not resist to the African cassava mosaic, resulting in continued yield loss.

- For other practices including row cropping with respect of the spacing between plants, crop rotation, or even the association of crops, there is a weak influence of the status of the field on their application. In general, households in Kalehe do not consider any criteria while establishing crops. The same plants are continuously installed on the same land without respecting the standards related to the spacing between the plants as well as the type of association to be established, and this both on owned and rented pieces of land.

- The duration of the contract, as previously mentioned, has an influence on the type of crops grown; that is why only annual crops are tolerated on rented lands. Regarding the fees for the land use, those resulting from kalinzi and bugule modes, that is owned ones, their holders are required to pay a customary fee to the customary authority as discussed earlier. But given current evolutions, only people who are attached to customary values do so, and this is not very common with young peasants. On leased land, the rental costs and other requirements are obligatory depending on the clauses binding the farmer to his lessor.

\section{Conclusion}

Customary land management in Africa has generally evolved as a result of factors that have influenced the history of this continent, mainly colonization and the land governance that resulted from it, but also practices that have developed over the years due to population growth.

For peasants, these evolutions have many consequences on their agricultural practices, from the types of crops to be grown to the technical itineraries to be applied. Briefly, these evolutions define the on-going agricultural systems in rural areas in Africa and particularly in South Kivu.

Precarious modes of land access will always negatively influence agricultural production as well as livelihoods in rural areas in South Kivu and in DRC in general. Thus, reforms to be envisaged should take into account this reality. Indeed, land reform, by facilitating access to land for those who depend of it, favours area stability following fair land distribution. It helps guarantee both the survival of those who cultivate the land and livelihood of the entire population, given the significant role of peasantry farming in food production (Fernandes, 2010; Jessenne et al, 2016). 


\section{References}

Ansoms, A., Wagemakers, I., Madison Walker, M., \& Murison, J. (2013). Land contestation at the micro scale: struggles for space in the African marshes. World development. Vol.54, 243-252. https://doi.org/10.1016/j.worlddev.2013.08.010

Ansoms, A., \& Hilhorst, T. (2012). Introduction: causes and risks of dispossession and land grabbing in the Great Lakes Region. In A. Ansoms \& T. Hilhorst (Eds), Losing your land (pp. 1-10). New York: James Currey.

Ansoms, A., Claessens, K., \& Mudinga, E. (2012). L'accaparement des terres par des élites en territoire de Kalehe, RDC. L'Afrique des grands lacs Annuaire 2011-2012, 205-226.

Bahati Shamamba, D., Ansoms, A., Bisimwa Basengere, E., Lebailly, Ph. (2021). L'agriculture familiale à l'épreuve de la concurrence foncière au Sud-Kivu. Conjonctures de l'Afrique centrale $N^{\circ} 97: 293-312$.

Bruneau, J., C. (2012). Enjeux fonciers à risques au Congo (RDC): contexte théorique et pratiques déviantes. Bulletin de l'Association de Géographes français, numéro «Terres et tensions en Afrique, sous la coordination de F. Bart».89(3), 474-485. https://www.persee.fr/doc/bagf_ooo4-5322_2012_num_89_3_8285

Chauveau, J., P., (1998). La logique des systèmes coutumiers. In Ph. Lavigne Delville (Ed.), Quelles politiques foncières pour l'Afrique rurale? Réconcilier pratiques, légitimités et légalité (pp. 66-75). Paris: KarthalaCoopération française.

Chauveau, J., P., \& Mathieu, P. (1998). Dynamique et enjeux des conflits fonciers. In Ph. Lavigne Delville (Ed.), Quelles politiques foncières pour l'Afrique rurale? Réconcilier pratiques, légitimités et légalité (pp. 243-258). Paris: Karthala-Coopération française.

Civava, M., R, Malice, M., et Baudoin, J., P. (2013). Amélioration des agrosystèmes intégrant le haricot commun (Phaseolus vulgaris L.) au Sud Kivu montagneux. [Online] Available: https://orbi.ulg.ac.be/bitstream/2268/1640o8/1/Am\%C3\%Aqlioration\%2odes\%2oagrosyst\%C3\%A8mes\%2oi nt\%C3\%Aggrant\%2ole\%2oharicot\%2ocommun\%2oau\%2oSud\%2oKivu\%2omontagneux.pdf (May 18, 2021).

Classaens, K., Mundinga, E., \& Ansoms, A. (2012). Competition over soil and subsoil: land grabbing by local elites in South Kivu (DRC). In A. Ansoms and T. Hilhorst (Eds.), Losing your land (pp. 82-102). New York: James Currey. Claessens, K. (2017). Land access and power. Case studies from Kalehe, DRC. Phd dissertation. University of Antwerp.

Eurac (2017). Terre, développement et conflits dans la région des grands lacs. Pour un engagement renforcé de l'UE et de la Suisse dans le domaine foncier au Rwanda, au Burundi et en RDC. [Online] Available: http://www.euracnetwork.org/sites/default/files/web_fr_brochure_terre_developpement_et_conflits_dans_la_region_des_grands_la cs.pdf (March 20, 2021)

Fernandes, B., M., (2010). Réforme agraire et Mouvement des sans-terre sous le gouvernement Lula. Alternatives Sud, Vol. 17-2010, 105-121 https://www.cetri.be/IMG/pdf/5-3.pdf

Heri-Kazi, A., \& Bielders, C. (2020). Dégradation des terres cultivées au Sud-Kivu, RD Congo: perceptions paysannes et caractéristiques des exploitations agricoles. Biotechnol. Agron. Soc. Environ. 2020 24 (2), 99116. https://popups.uliege.be/1780-4507/index.php?id=18544

ICCN (2010). Plan général de gestion 2009-2019. Parc National de Kahuzi-Biega. Bukavu : PNKB.

IFDP, CORDAID \& ICCO (2010). La problématique foncière et ses enjeux dans la province du Sud-Kivu, RDC. Synthèse des actes de la table ronde organisée à Bukavu du 10 au 11 mai 2010.

INS (2019). Annuaire statistique 2017. [Online] Avaible: https://www.ins.cd/wp-content/uploads/2021/o4/ANNUAIRESTATISTIQUE-2017-.pdf (05/18/2021)

Jayne, T., Yeboah, F., \& Henry, C. (2017). The future of work in African agriculture: trends and drivers of change. Research Department Working Paper No 25. International Labour office. [Online] Available: https://www.ilo.org/wcmsp5/groups/public/---dgreports/---inst/documents/publication/wcms_624872.pdf (January 20, 2021).

Jessenne, J., P., Luna, P., F., Vivier, N. (2016). Les réformes agraires dans le monde: introduction. Revue d'histoire moderne \& contemporaine 2016/4 n63-4/4 bis, 7-26. https://www.cairn.info/revue-d-histoire-moderne-etcontemporaine-2016-4-page-7.htm

Karsenty, A., \& Assembe, S. (2010). Renforcement des capacités institutionnelles liées à la réduction des émissions dues à la dégradation et à la déforestation (REDD) en vue d'une gestion durable des forêts du bassin du Congo. Diagnostics des systèmes de gestion foncière. Montpellier: Cirad.

Keita, Y. (1998). De l'essai d'un bilan des législations foncières en Afrique francophone de 1960 à 1990. In Ph. Lavigne Delville (Ed.), Quelles politiques foncières pour l'Afrique rurale ? Réconcilier pratiques, légitimités et légalité (pp. 374-382). Paris: Karthala-Coopération française.

Lavigne Delville, Ph. (1998). Introduction. In Ph. Lavigne Delville (Ed.): Quelles politiques foncières pour l'Afrique rurale? Réconcilier pratiques, légitimités et légalité (pp. 63-65). Paris: Karthala-Coopération française. 
Lonu, M., B., Gehrin, M., Cordonier, M., C., Moke, M. \& Wa Bassa, S., 2017. Le régime foncier congolais: du contact avec la civilisation occidentale à la veille de la loi $\mathrm{n}^{\circ} 73-021$ du 20 juillet 1973 dite Foncière. European Scientifc Journal April 2017, 211-225. https://eujournal.org/index.php/esj/article/view/9152

Lunze, L. (2000). Possibilité de gestion de la fertilité de sol au Sud Kivu montagneux. Cahiers du CERPRU, $28-31$.

Mansion, A., \& Broutin, C. (2014). Quelles politiques foncières en Afrique subsaharienne? défis, acteurs et initiatives contemporaines. Le Demeter 2014, 159-18o. https://agritrop.cirad.fr/570489/1/document_570489.pdf

Masiala Bode, M. (2021). Contribution des concessions agricoles périurbaines à l'approvisionnement alimentaire de la ville de Kinshasa. Thèse de doctorat Unikin-ULg.

Mugangu Matabaro, S. (1997). La gestion foncière rurale au Zaïre. Réformes juridiques et pratiques foncières locales. Cas du Bushi. Paris: L'Harmattan. Bruxelles : Academia-Bruylant.

Mugangu, S., (2008). La crise foncière à l'Est de la RDC. L'Afrique des grands lacs. Annuaire 2007-2008:385-413

Namegabe, P., R., \& Murhula, P. (2013). Contribution à l'analyse de la nature juridique des mesures de délocalisation des populations au profit de Banro Corporation à Twangiza. Conjonctures congolaise 2013, 130-154.

Ntampaka, C. (2008). Gouverance foncière en Afrique centrale. FAO. http://www.fao.org/3/ako18f/ako18f.pdf

Ouchinsky, A. (1966). Eléments de codification des coutumes fonciers du Bushi. In P. Masson (Ed.), Trois siècles chez les Bashi (pp 101-168). Bukavu: Imprimeries du Kivu-Presse.

Oyono, P., R. (2011). La tenure foncière et forestière en République démocratique du Congo (RDC): une question critique, des vues centrifuges. Yaoundé: Revue compréhensive de la littérature.

PNUD (2009). Province du Sud Kivu. Profil résumé: pauvreté et conditions de vie des ménages. [Online] Available: https://www.cd.undp.org/content/dam/dem_rep_congo/docs/povred/UNDP-CD-Profil-PROVINCE-SudKivu.pdf (January 21, 2021).

Soro, G., R. (2016). Migrations et enjeux fonciers en Côte d'Ivoire. Atelier de réflexion de l'ARGA du 15 au 16 décembre 2016. https://base.afrique-gouvernance.net/docs/tdr_foncier_en_rci.pdf

Utshudi Ona, I. (2008). « La gestion domaniale des terres rurales et des aires protégées au Sud Kivu: aspects juridiques et pratiques d'acteurs ». In S. Marysse, F. Reyntjens, \&S. Vandeginste (Eds), L'Afrique des Grands Lacs: Annuaire 2007-2008 (pp 415-442). Paris: L'Harmattan.

Valkonen, A. (2021). Examining sources of land tenure (in)security. A focus on authority relations, state politics, social dynamics and belonging. Land Use Policy 101 (2021). https://doi.org/10.1016/j.landusepol.2020.105191

Van Leeuwen, M., \& van der Haar, G. (2014). La gouvernance foncière comme un moyen de renforcement de l'Etat au niveau local dans l'Est de la RDC. Publication occasionnelle \#7.

Vlassenroot, K. (2005). Households land use strategies in a protracted crisis context: land tenure, conflict and food security in eastern DRC. FAO. http://www.fao.org/3/ag3o6e/ag3o6e.pdf. 